University of Washington Tacoma

UW Tacoma Digital Commons

SIAS Faculty Publications

School of Interdisciplinary Arts and Sciences

$9-2012$

\title{
Women Smuggling and the Men Who Help Them: Gender, Corruption and Illicit Networks in Senegal
}

Cynthia Howson

University of Washington Tacoma, chowson@uw.edu

Follow this and additional works at: https://digitalcommons.tacoma.uw.edu/ias_pub

Part of the African Studies Commons, and the Women's Studies Commons

\section{Recommended Citation}

Howson, Cynthia, "Women Smuggling and the Men Who Help Them: Gender, Corruption and Illicit Networks in Senegal" (2012). SIAS Faculty Publications. 19.

https://digitalcommons.tacoma.uw.edu/ias_pub/19

This Article is brought to you for free and open access by the School of Interdisciplinary Arts and Sciences at UW Tacoma Digital Commons. It has been accepted for inclusion in SIAS Faculty Publications by an authorized administrator of UW Tacoma Digital Commons. 


\title{
Women smuggling and the men who help them: gender, corruption and illicit networks in Senegal*
}

\author{
Cynthia Howson \\ Department of Interdisciplinary Arts and Sciences, University of \\ Washington, Tacoma, WA 98402-31 oo, United States of America \\ Email: chowson@uw.edu
}

\section{A B S T R A C T}

This paper investigates gendered patterns of corruption and access to illicit networks among female cross-border traders near the Senegambian border. Despite a discourse of generosity and solidarity, access to corrupt networks is mediated by class and gender, furthering social differentiation, especially insofar as it depends on geographic and socio-economic affinity with customs officers, state representatives and well-connected transporters. Issues of organisational culture, occupational identity and interpersonal negotiations of power represent important sources of corruption that require an understanding of the actual dynamics of public administration. While smuggling depends on contesting legal and social boundaries, the most successful traders (and transporters) strive to fulfil ideal gender roles as closely as possible. Ironically, trading on poverty and feminine vulnerability only works for relatively affluent women.

Through the paths of the most confusing and most crooked furrows in the depths of the Saloum, travelling at night, are a group of anxious and nervous women. They vie with one another in self-sacrifice and engage their 'cousins' of the customs service in a hellish game of hide and seek.

* I am grateful to the editor and two anonymous referees as well as Carlos Oya, Kate Meagher, Lynn Thomas and Pierre Ly for helpful comments on earlier drafts. Further thanks are due to my research assistant, Ousmane Ndao. Remaining errors and omissions are my own. 
These are the 'Ndioganes'. Of all ages, they are engaged in smuggling goods from Farafenni, Gambia. Customs officers call this activity fraud by infiltration.

(Cissé 2007)

The cross-border traders known widely in Senegal as ndioganes are women smuggling everyday commodities from The Gambia (sugar, tomato concentrate, batteries, fabric and cooking oil). Some head-load small quantities several times a day between remote periodic markets (loumas) and rarely encounter customs officers. Others depend on horse and cart drivers who specialise in smuggling, experienced in customs evasion and the art of the high-speed chase. For them, corruption occasionally results from encounters with officers who accept bribes or negotiate with smugglers on an ad hoc basis, particularly if some personal relationship is identified. But the most successful traders benefit from repeated contact with taxi drivers and customs officers, in which the quantity of smuggled goods and the relevant bribes are negotiated in advance with some predictability. Individual traders may negotiate directly with officers at the border or mobilise personal ties to officers. Alternatively, groups of women can develop strategies with transporters, who serve as intermediaries negotiating collective bribes near the official border point. These ties between kin, colleagues and acquaintances allow some women to benefit from cooperation with state representatives in order to circumvent the law. For this reason, I use the term 'illicit networks' to investigate social networks that serve to further opportunities for illicit accumulation (smuggling and corruption). The cooperative smuggling strategies involving rural women are quite distinct from the famously powerful and structured marabout networks in the holy city of Touba (for which, see Bako-Arifari 2006; Coulon 1981), but they are nonetheless important to rural economies. Moreover, the social regulation of networks for petty corruption provides insight into the poorly understood realities of public authority and the everyday corruption that pervades daily life in many developing countries (see Blundo et al. 20o6).

Efforts to stem the tide of corruption are central to the good governance paradigm. The World Bank (2001: 74) has suggested 'that policies promoting gender equality can help clean up governments and business', and that 'female participation in the public domain-can strengthen a country's governance and the effectiveness of its development policy. The world cannot forgo salutary effects as remarkable as these' (ibid. 28). To the extent that women's moral virtue can further 
such efforts, the goals of anti-corruption and gender equity can be seen as complementary. However, the literature that posits a link between gender and corruption ignores critical analytical questions, including the possibility that corruption impacts men and women differently, and that gender mediates access to opportunities for corrupt accumulation (see also Goetz 2007). Instead, this literature relates to findings regarding the tendency of women to be more averse to corrupt practice than men (two cross-national statistical studies, Dollar et al. 2001, Swamy et al. 2001, are widely cited). This is used almost solely to debate the instrumentalist potential of including more women in public office, while failing to elucidate the practical dynamics of corruption. This paper addresses this gap by investigating the gendered dynamics of illicit networks among women cross-border traders in Senegal and the men who facilitate or hinder their efforts. The moral regulation of these networks intersects with 'practical norms' ${ }^{1}$ of organisation in the transport sector and customs apparatus in a context of increasingly restricted state resources. These processes shape what Olivier de Sardan (2008) calls 'real governance'. Successful law-avoidance for everyone involved requires a delicate strategy of fulfilling occupational obligations, ideal moral and gendered boundaries, as well as representing specific class identities. Preliminary evidence suggests that the moral regulation of illicit networks does constrain women in important ways, but that this is likely to result more from the social importance of women's reputation among men than from women's own moral values.

Data and analysis are based on twelve months of fieldwork, from 2006 to 2008, including an in-depth survey with one hundred traders, as well as focus groups near loumas (periodic markets) and life histories. ${ }^{2}$ This is complemented by interviews with customs officers, transporters, market managers and traditional as well as government authority figures who constitute the illicit networks for women's smuggling and regulate their access. As Goetz (2007) points out, to the extent that women are less likely than men to participate in corrupt activity, it is crucial to consider how much this is determined by women's limited opportunities, particularly because the effect may be diminished as women gain access to public resources. If women presented with opportunities to engage in corruption are actually less inclined to do so, a greater understanding of patterns of corruption would require considering why women behave differently from men in response to specific political contexts, as opposed to simply theoretical claims about gender roles and norms. The problem with persistent assumptions either that women are inherently less corrupt than men or that they necessarily respond to 
opportunities for corruption in ways that are identical to men (cf. Alhassan-Alolo 2007; Sung 2003; Vijayalakshmi 2008) is that there is very little space for understanding actual patterns of corruption. A more nuanced approach would attempt to disentangle the dynamics of gender norms and their intersection with norms associated with the exercise of public authority, thereby elucidating actual patterns of access and responses to illicit networks.

The practical dynamics of rural law enforcement and public administration embody public authority and traders' conception of the state. As Lund (2006: 689) put it, the 'idea of the state is formed as a combination of people's everyday encounters with representatives'. Conflicting but symbiotic relationships between traders, transporters and officers mean that individual relationships are in a constant state of flux between contestation, competition, negotiation and cooperation. Meanwhile, the assumption that corruption and smuggling reflect a neatly defined illegality is reflected in the tendency to place both in a discourse of criminalisation. Thus, in a document for the World Bank, Ferreira et al. (2007: 359) write:

customs must endeavour to prevent the importation of illegal goods. Smuggling of drugs and weapons, plus large-scale smuggling of alcohol and cigarettes, places customs directly into the vortex of organized crime - with criminals using any means, from extensive bribery to intimidation and violence, to promote their illegal transactions.

That alcohol and cigarettes qualify as illegal goods in this assessment is further evidence that the authors make no effort to distinguish between different sources and techniques of corruption. Because illegal crossborder trade in West Africa tends towards trade in legal goods, the failure to distinguish different forms of smuggling in this context, though consistent with the notion of rule of law, is limited in its capacity to understand not only patterns of illegal behaviour, but patterns of economic activity as well. 'Indeed, the entire criminalisation thesis rests on a refusal to raise relevant analytical questions about the distinction between indigenous trading networks and organised crime' (Meagher 2003).

The relationships between customs officers and their civilian intermediaries, traders and transporters can be described as networks of illicit earnings, but do not reflect a clean dichotomy between legality and illegality. One may argue that this is simply evidence of 'bad governance', but it seems difficult to argue that a strategy of anti-corruption does not need to consider the practical dynamics of competing norms. For example, Lund (2006: 696) argues that 
legitimacy can be claimed by non-state institutional authorities, and that there may be 'a fine line between a fee and a bribe for issuing a deed or certificate, and between collecting a market-place tax and running a protection racket'. Similarly, Olivier de Sardan (2008) emphasises the notion of 'practical norms', which regulate professional behaviour at the interstices of official regulation and social norms. He argues that much informal regulation is not deeply rooted in tradition, moral values or culture, but is developed in response to changing circumstances. In Uganda, Titeca \& De Herdt (2010: 573) argue that practical norms help to 'make sense of the divergence between official laws and regulations and actually enforced practices', noting that the 'practices of government officials are also profoundly influenced by social norms and perceptions of the state held by illegal traders and transporters'. In Malawi, Anders (2004: 43) argues that reforms associated with 'good governance' and the 'combat against corruption' did little more than add 'an extra layer to legal pluralism within the civil service in Malawi'.

The claim to universality inherent in concepts of governance and the rule of law is problematic for a variety of reasons. If competing norms limiting the relevance and predictability of statutory law are simply seen as evidence of a policy or a state's success or failure, there is little space for understanding the actual dynamics of state management. Meanwhile, studies that consider the actual dynamics of corruption consistently cite the importance of competing norms in promoting corrupt behaviour (see, for example, Anders 2004, 2005; Blundo 2006; Blundo et al. 20o6; Olivier de Sardan 1999). Efforts to describe regulation in African contexts are associated with references to 'real governance' (Olivier de Sardan 2008), 'institutional multiplicity' (Hesselbein et al. 2006), 'legal pluralism' (Anders 2004), 'institutional bricolage' (Cleaver 2002), and 'twilight institutions', which 'effectively exercise public authority' outside the confines of the state (Lund 2006: $685)$.

Patterns of negotiation and corruption in this study contrast with popular assumptions about governance and the rule of law. The second section discusses critical debates surrounding gendered aspects of corruption, which continue to focus on the hypothesis that women are less corrupt than men. The next section analyses the role of masculinity encountered during fieldwork, connecting the practical importance of state capacity to notions of generosity, reciprocity and gendered obligation among officers and transporters. The final section illustrates the way in which competing norms are negotiated to structure and facilitate access to illicit networks for traders, linking ideals of femininity 
to questions of reputation, sexuality, feminine sacrifice and vulnerability. Each of these norms is mediated by class and other power relations, which help to explain instances in which men and women are able to deviate from ideal gender roles. My findings are broadly complemented by the few ethnographic studies of corruption, but far removed from donors' conceptions of 'governance'.

\section{DEBATES ON CORRUPTION, GOVERNANCE AND GENDER}

A possible factor in women's limited involvement in corrupt activities is their exclusion from or more limited access to corrupt networks, a point made originally by Swamy et al. (2001). Goetz (2007: 96) argues that access to corrupt networks may be the key determinant of differences in behaviour, although she is careful to note "the lack of research on how gender mediates access to networks for illicit earning, let alone the lack of explicit documentation about how such networks function'. There is some evidence illustrating how women's opportunities in illicit networks might be constrained, while the social pressure to engage in corruption may be more binding for men than women. Furthermore, some networks may become gendered as a consequence of practical norms. For Fassin (1985), the ways in which illicit networks are gendered play a critical role in determining access, but not all networks are gendered in the same way. The ability to trade in illicit pharmaceuticals near Dakar was typically controlled by the Mouride network, recruiting men who had been apprentices in the holy city of Touba. For this reason, illegal medicines in Pikine were never sold by women, except in tiny quantities. In Kaolack central market, on the other hand, the illicit trade in pharmaceuticals and bleaching cosmetics was almost entirely controlled by women. For Fassin $(1985: 166)$, 'variations by sex originate in differences in recruitment and in the composition of networks'. Here, access may be gendered as much by practical norms as by gendered social norms.

Olivier de Sardan (1999:47) notes that social obligation is not only a function of solidarity, but is also connected to shame, a distinctly social morality. A civil servant who refused to engage in any form of corruption would be subject to 'the shame that would inevitably befall his relatives, and which could be interpreted as his pride, his scorn for others, his lack of compassion, his rejection of family or friends, his hostility toward social norms'. The use of the masculine subject in this observation does not solely reflect the traditional universality of the masculine pronoun or the predominance of men in the civil service. Rather, as I argue in the 
next section, this precise representation of shame among civil servants is distinctly, if not uniquely, masculine. Meanwhile, women's involvement in these opportunities can include a balancing act that must be carefully managed. Smith (2007) describes a typical story of a small government contract in Nigeria. A secretary in a local government office convinced her boss to provide her husband with a contract to build a fence at the primary school, a form of corruption that is reminiscent of Anders' (2005) descriptions of civil servants' sense of moral obligation towards their secretaries. The favour was granted, greatly benefiting the family, while the village was grateful to receive some (albeit small) funding for its school. Nonetheless, the cost of the opportunity included disparaging rumours of a sexual relationship between the secretary and her boss.

There are very few empirical accounts of the ways in which pressures facing civil servants may be distinctly gendered. Although Selboe (2008) provides an illuminating account of the dynamics of network politics in Dakar, she does not analyse her data in terms of its gendered implications, which suggest important findings regarding women's access to illicit networks. For example, a female politician gained power in her political party through her leadership in a women's association and continued to develop her reputation and political network through those contacts. She gained praise, strengthening her constituency, by distributing rice to acquaintances and political supporters, or by securing sewing machines or vocational training for her association members (ibid:: 152). Even though women were able to promote their reputations in this way, 'some of them have withdrawn from party politics as they considered it to harm their respect and position among members' (ibid.). Here, women's pressure to engage in even minuscule forms of corruption is tempered by the greater pressure to conform to a feminine ideal. Men, by contrast, appear to engage their clientelist relationships differently. Municipal councillors are not salaried, yet one remains hesitant to leave his house at times because of the burden that results when 'some of the local women spot him ... expecting "a little something" like a bank-note in their hand' (ibid.: 149). Meanwhile, significant amounts of money are reserved for infrastructure contracts. The gendered implications of these networks are crucial. Women appear as burdensome constituents requesting small supplies, or as politicians who are extremely careful to safeguard their reputations and have very limited access to resources. Meanwhile, significant sums require the complicity of political actors as well as people working in urban infrastructure sectors, necessitating a wide network of contacts in a field highly dominated by men. 
In her work on micro-finance programmes in Bangladesh, Goetz (2007) found that the types of illicit behaviours available to men were very different from those available to women. Women fieldworkers might be considered 'local heroes' for helping borrowers profit from illegal cross-border trade or the misrepresentation of products. Male fieldworkers might be able to make deals with elite men, getting them access to loans that were ostensibly only available to the poor, or supporting a loan for a particular political constituency in exchange for a commission from the politician. Deals that involve establishing contacts between different spheres of power (political, business, industrial or rural elite) appear to be a particular site of women's exclusion from potentially illicit networks. Thus, in Senegalese loumas, Perry (2005: 216) argues that women traders are thought to "wait for customers to come, while men hustle and make "arrangements" (deals, often based on bribery) to sell their crops or livestock, or to solicit political perks'. This is not to suggest that female traders cannot be active in politics, figure among the rural elite, or develop profitable business relationships. They are, however, likely to be constrained in their strategies as they develop connections with a variety of men. Their ability to safeguard their reputations as upstanding women is crucial to this effort.

MASCULINITY, CLASS AND REGULATION IN ILLICIT NETWORKS

The dynamics of illicit networks are structured by competing institutions, including the intersection of moral obligations and the practical norms that adjust in response to changes in law enforcement, official regulation and state capacity. This section illustrates how competing norms facilitating corruption among public officials are exacerbated by practical weaknesses in state capacity, but regulated according to gendered ideals, impacting the accumulation strategies of men and women as well as their justifications for illicit behaviour. For men in a position of power, ${ }^{3}$ including civil servants and, to a lesser extent, drivers who own cars, the pressure to engage in corruption is deeply connected to notions of masculine generosity and more generalised norms of cooperative social behaviour. The qualities that define a trader, officer or driver as admirable or deviant illustrate ideal gender and occupationbased identities in Senegal. None of these depends on the legality of a practice. For officers, choosing the right time and place for strict or flexible law enforcement is a moral obligation based on gender, class and the responsible exercise of public authority. The drivers who help 
traders and befriend officers have some freedom in choosing whom to befriend and how involved they want to be in smuggling. However, the moral ground when investing simultaneously in relationships with law enforcement and smugglers can be tricky, and drivers have to negotiate so that everyone receives a sustainable portion of the pie.

The concept of corruption is almost universally stigmatised in Senegal as in many parts of Africa (for extensive discussions, see Anders 2005; Blundo \& Olivier de Sardan 2003; Smith 2007). 'At the everyday level, there is scarcely a conversation without hostile or disgusted references to corruption, either of the petty type of which one claims to have been a victim, or the upper crust type about which one has rumours to spread' (Olivier de Sardan 1999: 29). The contrast between people's outrage in the face of abstract notions of corruption, and the mechanisms that facilitate it in practice, become clear through in-depth fieldwork discussions of gendered social norms, moral obligations and people's everyday engagement with the state. Blundo (2006) argues that corrupt behaviour, even when it involves misappropriation of tremendous sums of money, is very rarely subject to professional sanction, let alone judicial investigation or imprisonment. Two customs officers recounted a famous local example. When a former head of a customs bureau continuously appropriated seized goods for months, the office was investigated because the revenue targets had not been achieved, to the dismay of the officers working there, who informally testified against him. After intervention on his behalf, 4 the officer not only escaped judicial prosecution, but was not even dismissed from his post. Instead, he was relocated to a less profitable bureau further from a border (Officer 2008 int.; Chef de poste 2008 int.). Meanwhile, 'petty corruption' by public agents or civilian intermediaries is openly tolerated in practice if not in conversation, by public agencies and private citizens.

Omar (2008 int.), a representative in the customs ministry, explained the moral quandary that faces officers. He left his position at the Port of Dakar, although it is known to be extremely lucrative, because the pressure to engage in extensive corruption was oppressive. He described the professional experience: 'You seize someone and then you get a call from an old teacher you haven't seen in fifteen years, who says, "come on now, you used to be a good student!"' For him, any application of the law can be associated with intense pressure from family, politicians or marabouts. Meanwhile, his departure was met with dismay and was difficult for people to accept. The pressure to juggle obligations when professional and social duties interact in this way does not necessarily provide a clear choice in a given circumstance. Moreover, these 
obligations are connected to the moral obligations of wealth and masculinity to provide financially for an innumerable circle of potential dependents. Pressure from within the organisational structure to be as corrupt as one's colleagues but not more so aggravates what this officer referred to as the 'unhealthy' professional environment of the bureau. As Omar's dilemma illustrates, when faced with the obligation to navigate the pressures of contradictory norms, the 'border between the legal and the illicit becomes fuzzy. It can be moved according to circumstances, by the users of the administration as well as by the government officials, pulled between the duties inherent in their positions and the pressure of social, identity, and political networks' (Blundo 2006: 808).

\section{State regulation and involvement in illicit networks}

The institutional mechanisms that facilitate corrupt behaviour in Senegal are related to those that allow the state to function, including the provision of basic public services. Restrictions on recruitment and voluntary retirements from the civil service in the early 199os led to a significant reduction in the size of the state. Combined with normal retirements, this amounted to over 9,60o losses out of 68,ooo total employees (Blundo 2006: 804). Only 138 agents represent the entire regional customs office of Kaolack-Fatick (ibid.), a massive geographical terrain receiving nearly all of the illegal imports arriving from The Gambia by land. The woefully insufficient transport infrastructure in the region is exacerbated by a shortage of public vehicles and funds for petrol. Meanwhile, customs officers are bound by revenue quotas and other productivity targets that are designed to incentivise productivity, but also motivate officers to elicit help from transporters and traders. This may include loans of vehicles, money, or petrol as well as storage of seized goods and information about smugglers, all of which are financed through the illegal sale of seized goods. One officer explained that the official regulation after a seizure is to fill out a form and send the entirety of the seized goods to a state warehouse. In practice, however, this is neither feasible, nor accepted. Instead, $10 \%$ of the merchandise is given to each of the two officers on duty, the bureau chief and the informant, leaving at most $60 \%$ of the seizure for the state treasury. He added: 'it's not normal, but it has to be that way' (Officer 2008 int.).

Customs officers remain in a given post for fewer than three years, an anti-corruption measure intended to inhibit the development of social 
ties. The lack of familiarity associated with these short appointments is mediated by help from long-term community members, who are recruited as trackers, informants and intelligence agents (indicateurs). One such employee explained that there are intermediaries at every level of the customs organisation, including working in the bureau, in charge of all movement of a seizure from confiscation to storage, inventory, organisation and transit (Indicateur 2008 int.). These civilian informants are needed for their skills in navigating local terrain, both human and physical, although it is illegal to hire them. Moreover, they are widely criticised in local communities because they operate in secret, illegally, and are members of the nearby village community, contesting norms of solidarity and profiting at the expense of poor traders. Blundo (2006: 816) explains that 'just like the customs officer, the informer, the tracker or the tax collector, they are objects of avoidance and held in contempt by the populations. The customs officer and the juuti are cursed characters, who will go to hell ("dina nu dem safara”).' Most people (especially women) I spoke with were more reserved in their moral condemnations than to use such phrases, but did not hide their contempt.

Several informants were quick to point out that customs officers may use the lack of administrative resources as an excuse to legitimise their extortion of goods and services from civilians, or as a front for their own appropriation of seized goods. Whether relationships are forged through purely illegal economic exchange or through a practical exchange of services, the individuals involved strengthen their relationships with one another. In this way, vertical relationships characterised by dependency or even exploitation and extortion may also be considered patron-client relationships where affective ties and reciprocal obligation play a role. Moreover, administrative exchange may be a direct means to strengthen affective ties, as in the case of officers and transporters who emphasise that their relationships are characterised by friendship.

Reciprocity is particularly important between motorised transporters and customs officers. Because they own cars and cross the same border, they are likely to cross each others' paths frequently. An indicateur (2008 int.) explained that drivers working with smugglers are often extraders and sometimes indicateurs as well, so that they may accept products from a trader and then call a customs officer with the tip. One officer indicated that drivers and officers tend to be close, and that drivers receive significant tolerance. Those who benefit from affective ties with officers and receive tolerance for their own illicit imports are 
likely to be among those who may be hired as drivers, or provide officers with information about other smugglers. When asked if the close relationship applied only to drivers of motorised vehicles, the officer (2008 int.) nodded, explaining that the horse-cart drivers' 'path is suspicious', referring to their tendency to lead officers in dangerous chases. Similarly, when asked about friendships with customs officers, a horse-cart driver (2008 int.) replied that they may know some officers, but added, 'douane dou xarit', meaning 'customs are not friends'. Meanwhile, motorised transporters are more likely than the general population to share experiences and to be closer in socio-economic status to officers. This is partly because owning a car is an indication of relative privilege and being a customs officer is an indication of significant privilege, but also because these activities are associated with similar degrees of mobility, contact with large numbers of people, flexible work hours and leisure time spent away from home.

For example, an officer described his own experience of a typical network between the customs and transport sectors, illustrating forms of cooperation and elements of the organisational culture of the workplace. He explained that one gendarme (military personnel typically assigned police duties in rural areas) is posted to a customs bureau in order to supervise the officers as an anti-corruption strategy. This cooperation has advantages, he argues, but is a 'total failure' as an anticorruption strategy because, of course, the officers cooperate. They are all friends with Abdou and Modou, two active drivers/smugglers from the nearby city of Kaffrine, and a worker at the gas station who provides petrol on credit. They cooperate with other informants. When officers come from the Fatick customs bureau, hoping for work because their own region is unprofitable, they are allowed to operate outside their official jurisdiction as long as they refrain from storing seized merchandise with village heads or taking official credit for their seizures (Officer 2008 int.). This arrangement may benefit officer morale and cooperation, but it is noteworthy that these officers are allowed to confiscate smuggled goods solely for the purpose of personal enrichment.

Customs officers in rural areas are particularly affected by the conflicted nature of their relationships. Much of their contact with local people involves an unequal exercise of power combined with their already tenuous reputations in the community. Because officers are regularly transferred, traders and their allies must continue to reinvest in these relationships and renegotiate agreements as new officers are assigned to the area. New arrivals and especially young recruits 
are notorious for applying the law too strictly or demanding exorbitant bribes. As they gain experience, say informants, they learn to 'calm down'. Because new arrivals are unfamiliar with local institutions, everyone must be more careful when they are involved. For example, seizures rarely happen within the confines of the louma. Should this occur, according to the manager of Nioro louma, private negotiation quickly follows between the trader (or a person asked to help her) and the officer in question. If the officer is a new arrival, he will be informed of the local ways and, typically, seized goods will be returned for a small bribe. This is a good example of the multitude of ways in which public authority may be exercised by a variety of people. The politically appointed but largely powerless manager of the louma, the commanding presence of the person chosen to lay down the law on behalf of the trader, the police officer and the customs officer all play a role in regulation, and the customs officer, the one person who is legally empowered to act in the situation, becomes the enforced.

\section{Masculinity and generosity among transporters and customs officers}

Customs officers operate in murky moral territory, as the line between corruption/theft and tolerance/reciprocity can be difficult to define. Although corruption in general is seen pejoratively, village-based respondents, including traders, their families and other informants, were more critical of officers' refusal to accept bribes than their willingness to negotiate. Refusal to accept bribes is seen by some as evidence of theft (that the officer intends to sell the seized merchandise for his own benefit). Others simply felt that officers who refused bribes were inflexible or insensitive. When officers accord 'tolerance' to friends and family, it is not seen as corruption and is a moral obligation. It is unthinkable to most of my respondents that an officer would require full payment of dues or seize the prohibited products of a family member (which helps to explain why flexibility tends to be accorded to the most privileged smugglers). Tolerance justified by sympathy is seen as both a moral good and a masculine ideal. It is understood that officers will judge their leniency on a case by case basis considering the need of the trader and the degree of separation between officer and trader (whether they have a friend in common, for example). Furthermore, as an indicateur (2008 int.) explained, if an officer refuses ever to show flexibility by showing tolerance, he 'will not end well', but will suffer mystically as a consequence of his actions. In this way, the social pressure 
to engage in corruption may be exacerbated by officers' desire to prevent multiple forms of reprisal from local communities.

Because male cross-border traders and horse-cart drivers smuggle in higher volumes than women, officers perceive them to be more important targets for seizure. Because women trade in smaller quantities, some officers referred to them as non-threatening and distinguished between criminal smugglers or la fraude noire (primarily men) and subsistence smugglers (primarily women). While accumulation to 'get rich' was discursively linked to women's sexuality, accumulation as evidence of criminality was discursively linked to masculinity. None of the women in the current sample would qualify as criminal smugglers, whose imports are quantified by the truckload

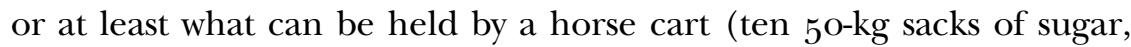
for example). This is very likely a result of exclusion not only based on women's more limited access to investment capital, but also women's more limited access to illicit networks because of the negative connotations associated with women's independent wealth. Officers felt that it was necessary, both morally and to safeguard the goodwill of the community, to show occasional flexibility to subsistence traders who traffic in low volumes (for instance by confiscating only half of a trader's goods).

Descriptions of the type of women who deserve support also indicate the ideal masculine roles that informants define for themselves. The ideal masculine role is represented by strength, generosity, moral authority, discipline and the ability to provide. One driver, Dembe in Nioro (2008 int.), exemplifies these characteristics in his presentation of himself, as he tells the story of his decision to help traders. Having been in the army, Dembe has learned discipline and respect for the law. He considers customs officers his 'brothers in arms' and initially felt that illegal cross-border trade was a crime. After having spent some time in Nioro, however, he came to know some of the local cross-border traders who requested his help. He sympathised with their predicament, explaining that these are poor women, pushed by 'social reasons' to engage in illegal trade, and are only trying to survive. When they asked for his help, he was unable to refuse. Further, he is unusually able to help because of his car and his connections to customs officers (making it easy to negotiate a collective bribe for five women at once). He also benefits from this exchange by strengthening his own reputation and social network. Dembe's sense of obligation conforms to the ideal masculine role of a strong and generous provider, able to protect his friends' ideal feminine vulnerability. Of course, the women Dembe 
has chosen to help are not among the most vulnerable traders. Class plays an important role in determining which poor women a driver might help, in that the most vulnerable traders do not have the opportunity to befriend Dembe. His education, relative wealth and connection to customs officers place him in a socio-economic position that is not accessible to those traders who are most in need of help.

Transporters typically have the luxury of choosing whether and how much to help traders. Some horse-cart drivers provide free transport for female traders in their families, while others charge their own wives full price $\left(\mathrm{CFA}_{5}\right.$ oo per sack of sugar, for example). The same diversity applies to motorised transporters, implying that generosity is a moral good, but the lack of generosity does not appear to be sanctioned. This reflects an important popular distinction driving norms based on solidarity. A transporter may choose to charge his family members as paying customers because the fee represents his own personal income. Meanwhile, a customs officer does not appear to have the same luxury (of requiring family members to pay tariffs) because, as Olivier de Sardan (1999: 31) described in the case of the village infrastructure, the funds 'belong to the state, that is to the outside world, and therefore to nobody'. Reciprocity is a moral obligation in Senegal, but motorised drivers are able to choose their level of investment in particular relationships, which gives them the freedom necessary to negotiate whom to help and what they can expect from officers. The inability of horse-cart drivers to make the same choices is a reflection of the limitations of class and geography in their social access to officers.

\section{SEXUALITY, REPUTATION AND WOMEN'S MARGIN OF MANOEUVRAB ILITY}

Gendered access to illicit networks is distinctly reflected in the way traders depend on collaboration with men, and state actors in particular, throughout the process of supply acquisition, transit and sales. Men facilitate access to transport networks in collaboration with customs officers, other transport networks in the evasion of customs officers, and negotiation in the event of seizure, thereby exercising control over women's opportunities. These relationships intersect with those in which male suppliers provide credit and male kin provide moral support, giving women permission to trade. Access to opportunities for illicit accumulation thus depends on men's support in a way that conditions women's margin of manoeuvrability in pushing the boundaries of gender norms. 
For women, the key determinants of acceptable behaviour are greed and sexuality. This section begins by elucidating the role of sexuality as a strategy of male dominance impacting women's behaviour. Next, the strategies of the most successful traders highlight the importance of class in women's access to opportunities for corrupt accumulation. Ironically, it is the wealthiest women who are able to use feminine poverty and vulnerability to obtain consistent help. However, some women successfully challenge the boundaries of ideal femininity because they command significant economic and social resources.

Importantly, most traders I spoke with $(60 \%)$ are never able to receive 'tolerance' (negotiation upon seizure) or even successfully bribe customs officers. This is true of $87.5 \%$ of the poorest women (all but two), and $37.5 \%$ of the wealthiest traders. ${ }^{5}$ Within the bottom two wealth quintiles, four women have successfully kept some portion of their products through a bribe, without necessarily benefiting from help (bribes ranged from $18 \%$ to $45 \%$ of the value of their products). Meanwhile, it is among the wealthiest group of traders that diverse strategies of law-avoidance begin to appear: three who travel to Banjul and successfully hide their products or negotiate tariff reductions; several who have established relationships involving the complicity of customs officers; and those who benefit from the help of well-connected transporters. It is worth noting here that class is apparent in the sample in ways that are occasionally quite subtle. However, these examples reflect glaring differences in power, including quantifiable access to durable assets (defined here as 'wealth'), as well as qualitative evidence of well-being and power (education, health, market power and connections to powerful men).

\section{Sexuality and gendered expectations}

The most commonly cited criticism of women's involvement in illegal cross-border trade is the risk of adultery or prostitution. It is common knowledge that some women have relationships with customs officers, thereby receiving tolerance and other forms of support, although there is very little empirical evidence that the practice is widespread or available to women who are not wealthy and well connected. Meanwhile, men who criticise women's smuggling point out that young and attractive women are more successful. Interestingly, this topic was only mentioned by relatively wealthy, urban informants. Although the topic itself is taboo, it is also likely that class and geography play important roles in determining officers' relationships, so that poorer traders 
and village-based traders are less likely to establish social ties to officers. This is why the moral pressure to engage in corruption tends to be concentrated in the wealthiest circles. Officers who are based near the border often rent a flat in the better equipped town of Wack in order to be less conspicuous and more comfortable, so their daily interactions with rural smugglers are rarely social. Meanwhile, the fourteen traders who are able to successfully evade seizure are over one quintile wealthier than the average trader, and all fall within the most successful quintile in terms of trading capital. Seven of them are from the town of Nioro.

One driver, Dembe (2008 int.), explained that illegal trade was morally risky. When asked what morals were at risk, he described young, seductive women who risked becoming promiscuous, explaining that there is a 'veiled competition between neighbours, between rich and poor'. The implied relationship between promiscuity and competition among traders illustrates the tenuousness of women's reputations and the complexity of adhering to a feminine ideal. This is reminiscent of Perry's (2005: 216) finding that men in loumas 'link economic liberalization and market activity to sexual liberty and immorality. Men deride petty trade by conflating it with female sexuality.' Here, competitiveness is a trait not conforming to the feminine ideal, particularly as it relates to class antagonism. 'Getting rich' as a motive for women's smuggling was cited by several informants as an inherent moral pejorative and a dangerous precedent. Women who become wealthy in trade may 'just want their freedom' rather than simply seeking 'household maintenance'. For this reason, women's ability to protect the image of altruistic motives for income generation appears to be an important determinant of labour participation. The alternative of 'wanting one's freedom' refers to financial independence from one's husband and is related to the concern that cross-border trade will increase divorce rates. As an example, Dembe cited a particular case in which a metalworker was less wealthy than his wife and she divorced him. It is worth noting that, although several accounts of divorce in the sample were related to financial issues, there is no case of divorce that occurred after a woman became successful in trade, and there are very few cases in which the trader appears to be financially better off than her husband.

The role of sexuality in obtaining support from officers is not limited to sexual relationships. The observation that young and attractive women are more likely to get tolerance was cited by several men as evidence for a variety of conclusions, including that married women should not smuggle, that unmarried women should not smuggle, and 
as an indication that sex for favours ${ }^{7}$ is common among traders. Importantly, this is not true of most men I spoke with. A large majority of male respondents described smuggling as an economic necessity for women in general. Several male informants explained that border villages ${ }^{8}$ lack industry or employment opportunities, and women have a budgetary responsibility that is difficult to fulfil. In villages, most respondents did not see a moral downside to smuggling, but explained the primary disadvantage as the risk of seizure. Even among rural informants who were hesitant about smuggling, ${ }^{9}$ illegality never appeared as part of a moral discourse. On the other hand, informants in the larger town of Nioro (a shop-owner, a driver and an officer) felt that smuggling was only acceptable for women who were otherwise unable to fulfil their household responsibilities, and each of them referenced sexuality as the reason.

That sexuality is a factor (be it in the form of sexual relationships or women simply benefiting from their attractiveness) in the trader-officer relationship was mentioned by several men and no women. In part, this is because the entire discourse reflects poorly on women, but also because the assertion is a tool of male dominance, used precisely because it is the most effective way to denigrate women's activities. The tendency of male informants to associate smuggling with sexuality reflects more than the concern about actual sexual behaviour. For some men, women's skill and involvement in revenue-generating activities is linked to their sexuality. As one man noted in a study of loumas, 'women are better sellers than men since women have more charm (bayre)' (Perry 2005: 216). Women's power is thus discursively linked to their sexual allure. As a moral issue, whenever sexuality was mentioned, the discourse was pejorative (including words like 'inappropriate', 'risky', 'dangerous' or 'adultery') only as it related to women or their husbands (who are responsible for allowing them to trade). Sexuality for officers, however, seems to be morally neutral territory as it was only referenced as a fact.

\section{Manipulating femininity}

Investing in an effective support network for illicit accumulation requires cultivating the kind of reputation that makes one seem worthy of help. Some of the more effective traders emphasised their femininity in particular relationships, further illustrating ideal feminine roles. The most successful strategy involves prior negotiation with a customs officer, a practice that effectively prevents the risk of seizure (with a manageable 
bribe) and seems to be distinctly connected to an ability to represent ideal feminine roles. In most cases, 'cultivating femininity' involved proactively showing deference to one's husband, or describing the ways in which one's husband is a good provider and is supportive of her activities. Several successful (and wealthy) women are heavily involved in volunteer activities or those associated with health or education, and describe their activities in terms of solidarity. This is in distinct contrast to the majority of traders who rarely mentioned their husbands, except in response to questions about them. Most traders appeared to be preoccupied with matters of practical necessity.

One successful woman from Nioro, Amie, explained that she began trading when her husband lost a high-paying job with an NGO in 1986. Because he had always been an excellent provider and had never denied her the things she needed, it was important for her to do everything she could to keep the family afloat when he was laid off. For start-up capital, he gave her the CFA250,ooo severance package from the NGO. This tone incorporates several facets of the ideal gender roles in Senegal. Not only does she show deference to her husband, but she protects the image of his masculinity by portraying him as the consummate provider. In order to provide for her family, she began gardening, baking cakes to sell as well as cross-border trading. Amie's case is exceptional, in that she is one of only three women to have received help from their husbands to begin trading. ${ }^{10}$ This is the only example of such a substantial portion of a husband's own capital, and was a much larger gift than other women received from anybody. Only one trader in the sample began with more, at CFA265, ooo, and her brother was a customs officer in Farafenni.

When Amie began cross-border trading, she went first to the customs bureau at Farafenni to explain her predicament. Because her husband was laid off, she was forced to earn as much as possible (implying she had to provide more than would typically be expected of a wife). Officers were sensitive to her problem and allowed her to buy a particular quantity of banned goods. As a strategy, this was especially effective because her tolerance was negotiated before she purchased her supplies, protecting her from seizure. When discussing time away from home, she is unusually careful to point out the importance of being available for her children. She is humble and charismatic, seeming neither to complain nor to martyr herself. She thus appears a consummate wife and mother, made vulnerable by a circumstance beyond her control, having no choice but to engage in illegal trade. This 
approach is so effective that she is almost never categorically denied tolerance (although the amount she is allowed to buy has varied).

What is telling about Amie's experience is that she established relationships with customs officers ostensibly on the basis of a financial crisis beyond her control, exaggerating her vulnerability and skilfully displaying her femininity, to such an extent that this explanation (her husband having been laid off) continued to be effective for the rest of her career, the twenty-one years she had been trading before the current survey. Meanwhile, in reality she is an innovative and intelligent businesswoman, with significant financial and social resources available to her, and is very independent from her husband. Her husband was present at every occasion I visited her. They appear to have an extremely affectionate relationship, but her husband did not exert his authority overtly. Moreover, she was one of very few women to travel to the Gambia in the evening, a particular measure of independence because others may associate it with an opportunity to engage in romantic liaisons with officers. It is also, of course, an opportunity to sell and garden more actively and be with her children during the day, but the fact that her husband was not critical of this behaviour is indicative of their nontraditional roles. She is, by any standard, one of the least vulnerable women in the sample.

A remarkably similar strategy is equally effective for Fatou, whose vulnerability stems from a physical disability. This case is reminiscent of similar findings in Congo, where disabled women as a group are granted flexibility from customs officers (Devlieger et al. 2010). Fatou, a wealthy and well-educated trader, has been the main contributor to her household since her father died in 1996. Her husband (a metalworker turned 'politician') lives elsewhere, but visits and contributes financially. In addition to cross-border trade, she sells snacks and teaches adult literacy. Her multiple income sources allowed her to begin trading with CFA1 80,ooo, a sum surpassed by only five traders in the sample, of whom only two earned the sum independently. She is able to obtain formal credit (where interest rates are lower) and trade with significant mobility in Mauritania, Dakar and Banjul. She credits expansion in her trade to business skills she acquired in a management course. Her ability to engender compassion on the part of customs officers is based on a physical disability. When she was four years old, she fell from a significant height and grew up with a noticeable limp. She walks slowly but does not otherwise suffer from limited mobility. Because she has a disability, she explains that customs officers pity her and are willing to give her tolerance, which she negotiates prior to purchasing her supplies. 
These women have been able to curry favour with local customs officers ostensibly as a result of vulnerability beyond their control. However, the resources on which they draw to obtain this support (startup capital, management skills, convenient transport, credit) were available precisely because they were not comparatively vulnerable at all. Indeed, the strategy of prior negotiation is extremely rare, for several reasons. First, it is only possible for women who are able to engender some element of affection from officers. There are good reasons to imagine that this may be mediated by class in the same way as other social investments. Second, it requires a degree of autonomy from one's husband not enjoyed by all women. The decision to approach a customs officer in advance and seek assistance is precisely the kind of behaviour that is attached to rumours of sexual impropriety. Third, this opportunity is only possible for women who have physical access to a customs facility.

\section{Alternatives to feminine vulnerability}

For traders with significant resources, prior negotiation is not the only successful strategy to gain the complicity of law enforcement, nor is conforming to a feminine ideal. Mariam benefits from a wide margin of manoeuvrability because her husband used to be a customs officer. Because he transports her products for her, she never has to worry about seizure. Moreover, she is less obligated than most traders to invest in solidarity with customers. While nearly all traders provide products on credit, most emphasised the need to respond with diplomacy or understanding to those who are unable to pay. This reflects a similar strategy for success to that described by Ntseane (2004) in Botswana. There, traders were obligated to invest in business relations by exhibiting characteristically feminine traits, promoting solidarity and cooperation, without appearing competitive. Mariam, on the other hand, uses her contacts within the gendarmerie to intimidate customers into paying back their loans, an approach that would be neither effective nor appropriate for other women, even among those familiar with gendarmes.

Adama reflects an atypical level of success for a woman, almost singlehandedly providing the household income that puts her within the wealthiest quintile. She has been engaged in cross-border trade for twenty years, having established a wide network of contacts and a significant store of capital. Her husband does not appear to contribute to the household income as they have no land and he has limited vision. He describes her contribution as 'exemplary'. Because she is friendly 
with several customs officers in the region, and provides them with loans when they lack resources in the field, she often has the opportunity to purchase seized goods. She also claims to benefit from the regulations limiting direct seizure by indicateurs. During our interview, whenever her husband spoke, or my research assistant spoke to me in French, she slept. When a visitor came to see her, she told her husband to lie and say she was not at home. Although my research assistant typically refrained from commenting on the responses and behaviour of respondents, in this case, he felt compelled to evaluate the marriage, reflecting many of the gendered moral norms described above. He explained that in some marriages, when a wife is more financially secure than her husband, she is able to 'torture' her husband. He is obliged to compliment her (describing her as an exemplary wife) and lie for her (a particularly egregious sin in Senegal), because she controls the household income.

Whether traders exaggerate their femininity in order to curry favour or push the boundaries of gender norms, the social resources that lead to success for a trader involve fulfilling the right identities at the right time, and investing in the right relationships with the most wellconnected people. These strategies are rarely available to the poorest women.

\section{* * *}

This paper has investigated the role of illicit networks in facilitating corruption and successful law-avoidance among cross-border traders. It contributes to a little-studied area of scholarship regarding gendered aspects of corruption, arguing that understanding this relationship requires an analysis of the practical dynamics of corrupt behaviour and the role of gendered social norms in structuring access to illicit networks. By examining the way in which men and women invest in and compete for access to these networks, it shows some of the ways in which corruption impacts men and women differently and, particularly, ways in which gender mediates opportunities for corrupt accumulation in Senegal. Access to these networks is distinctly gendered, for a variety of reasons, including patterns in labour participation, access to associational and political networks, and social norms that criticise women's wealth and conflate accumulation with sexual impropriety. Despite a discourse of generosity and solidarity associated with these networks, opportunities for corruption are mediated by class and gender in a way that favours social differentiation, particularly in so far as they depend 
on geographic and socio-economic affinity with customs officers and well-connected transporters. Although women's illicit enterprise is likely to be constrained in important ways, this may result more from their reputation among men, than from their own moral values.

The institutions that regulate illicit networks include gendered moral obligations as well as practical norms that adjust in response to changes in law enforcement and state capacity. Issues of organisational culture, occupational identity and interpersonal negotiations of power represent important sources of corruption that require an understanding of the actual dynamics of public administration. While limitations in the resources of the state necessitate the use of some auxiliary bureaucrats, officials also use affective or economic networks as part of strategies for personal accumulation or investment in community solidarity. The dynamics of these networks in structuring accumulation strategies and facilitating corruption in the customs apparatus are far more complicated than the literature on corruption and governance implies. Indeed, the fundamental difference between donors' understanding of corruption and its popular representation in Senegal is an important factor in the unwillingness and inability of citizens to hold leaders accountable for specific corrupt behaviours, reflecting the analytical limitation of 'good governance' as an approach to anti-corruption strategies.

N O T E S

1. 'Practical norms' refer to the intersections and divergence between official regulations and social norms that characterise professional practice and 'real governance'. See Olivier de Sardan 2008 for elaboration of this concept. See Titeca \& De Herdt 2010 for a study of practical norms regulating smuggling and corruption in Uganda.

2. The survey sought to identify the determinants of labour participation and success among cross-border traders, and included extensive research on topics beyond the scope of the current paper (including life experiences with marriage, reproduction, education, health and occupation). The sample includes women cross-border traders selling daily commodities that are typically smuggled in any of five loumas (periodic markets) near the Gambian border. Louma villages were selected in an effort to maximise variation (village population, distance to an official border point, size and relative importance of the markets). After an initial familiarisation in ten loumas in Senegal and The Gambia, focus groups in the five sampled villages helped to identify key concerns of traders and village residents, and to provide an approximate sample frame. Individual traders were then sampled randomly, where possible, and purposively when necessary to maximise variation between women (especially with respect to age, relative wealth, marital status, membership in women's organisations, means of transport and experience trading). Four life histories helped to contextualise and triangulate fieldwork data.

3. To hold a privileged class position in the current paper is to be in a position of power, able to command economic and social resources in comparison with others in the community.

4. The bureau chief or chef de poste in Keur Ayib (18.3.2008 int.) indicated such intervention is common, but did not know who, in particular, had protected the officer in this situation. When asked he answered in English: 'Who knows? Other customs officers, marabouts, family.'

5. For numerical data, 'wealth' refers to quintiles calculated through an asset index using principal components analysis based on access to durable goods for the sample of one hundred 
cross-border traders. This approach follows Filmer \& Pritchett 2001, and is comparable to the method used in the Demographic and Health Survey in Senegal. 'Class' refers to a combination of wealth, as defined by the index, and qualitative evidence of relative power and wellbeing.

6. Unlike discourses associated with sexuality, greed and competition are also prime targets of women's condemnation of other women.

7. This behaviour is very rarely described as 'prostitution', indicating that the moral assessment of such a relationship, while not positive, is not as harshly viewed as prostitution.

8. References to 'border villages' indicate that proximity to the border is a distinctly identifying feature of the community, rather than that underemployment is a distinct phenomenon of border villages.

9. Informants whom I describe as 'hesitant about smuggling' include a son who campaigned to stop his elderly mother from trading, and a village head whose village had decided not to engage in smuggling because they were often witness to seizures.

10. The lack of financial assistance from husbands is noteworthy, as $23 \%$ received gifts from family members. It is also somewhat unusual in West Africa (cf. Guérin 2006; Meagher 2001).

\section{R E F E R E N C E S}

Alhassan-Alolo, N. 2007. 'Gender and corruption: testing the new consensus', Public Administration and Development 27, 3: 227-37.

Anders, G. 2004. 'Like chameleons: civil servants and corruption in Malawi', Bulletin de l'APAD 23-4: $43-67$.

Anders, G. 2005. 'Civil Servants in Malawi: cultural dualism, moonlighting and corruption in the shadow of good governance', PhD dissertation, Leiden University.

Bako-Arifari, N. 2006. “We don't eat the papers": corruption in transport, customs and the civil forces', in Blundo \& Olivier de Sardan, Everyday Corruption and the State, 1 77-224.

Blundo, G. 2006. 'Dealing with the local state: the informal privatization of street-level bureaucracies in Senegal', Development and Change 37, 4: 799-819.

Blundo, G. \& J. P. Olivier de Sardan. 2003. 'La corruption au quotidien en Afrique de l'Ouest: approche socio-anthropologique comparative: Bénin, Niger et Sénégal’, Working paper 17, Mainz: Johannes Gutenberg Universität.

Blundo, G. \& J. P. Olivier de Sardan, eds., with N. Bako-Arifari \& M. T. Alou. 20o6. Everyday Corruption and the State: citizens and public officials in Africa. London: Zed.

Cissé, M. 2007. 'Les "Ndioganes" dans le Saloum: dans le secret des maîtresses de la fraude à petites doses', L'Observateur (Dakar), 16.11.2007.

Cleaver, F. 2002. 'Reinventing institutions: bricolage and the social embeddedness of natural resource management', European Journal of Development Research 14, 2: 11-30.

Coulon, C. 1981. Le Marabout et le Prince: Islam et pouvoir au Sénégal. Paris: A. Pedone.

Devlieger, C. 2010. 'Disabled traders at "Beach Ngobila": issues of identity and state, technology, disability social networks, and gender', paper presented at the 2010 ABORNE conference, 'CrossBorder Trade in Africa', Basel, 8-1 1 September.

Dollar, D., R. Fisman \& R. Gatti. 2001. 'Are women really the "fairer" sex? Corruption and women in government', Journal of Economic Behavior and Organization 46, 4: 423-9.

Fassin, D. 1985 . 'Du clandestine à l'officieux: les réseaux de vente illicit des medicaments au Sénégal', Cahiers d'Etudes Africaines 25, 98: 161-77.

Ferreira, C., M. Engelschalk \& W. Mayville. 2007. 'The challenge of combating corruption in customs administrations', in J. E. Campos \& S. Pradhan, eds. The Many Faces of Corruption: tracking vulnerabilities at the sector level. Washington, DC: World Bank, 367-86.

Filmer, D. \& L. Pritchett. 2001. 'Estimating wealth effects without expenditure data-or tears: an application to educational enrollments in states of India', Demography 38, 1: $115^{-32}$.

Goetz, A. M. 2007. 'Political cleaners: women as the new anti-corruption force?', Development $\mathcal{E}$ Change $38,1: 87-105$.

Guérin, I. 2006. 'Women and money: lessons from Senegal', Development and Change 37, 3: 549-70.

Hesselbein, G., F. Golooba-Mutebi \& J. Putzel. 2006. 'Economic and political foundations of state-making in Africa: understanding state reconstruction', Crisis States Working Paper 2, 3, available at: www.crisisstates.com/Publications/wp?WPseries2/wp3.2.htm. 
Lund, C. 2006. 'Twilight institutions: public authority and local politics in Africa', Development and Change $37,4: 685-705$.

Meagher, K. 2001. The Bargain Sector: economic restructuring and the nonfarm sector in the Nigerian savanna. Farnham: Ashgate.

Meagher, K. 2003. 'A back door to globalisation? Structural adjustment, globalisation \& transborder trade in West Africa', Review of African Political Economy 3o, 95: 57-75.

Ntseane, P. 2004. 'Being a female entrepreneur in Botswana: cultures, values, strategies for success', Gender and Development 1 2, 2: 37-43.

Olivier de Sardan, J. P. 1999. 'A moral economy of corruption in Africa?', Journal of Modern African Studies $37,1: 25^{-5}{ }^{2}$.

Olivier de Sardan, J. P. 2008. 'Researching the practical norms of real governance in Africa', Discussion Paper 5 , Africa Power and Politics Research Programme.

Perry, D. L. 2005. 'Wolof women, economic liberalization, and the crisis of masculinity in rural Senegal', Ethnology 44, 3: 207-26.

Selboe, E. 2008. 'Changing continuities: multi-activity in the network politics of Colobane, Dakar', $\mathrm{PhD}$ dissertation, University of Oslo.

Smith, D. J. 2007. A Culture of Corruption: everyday deception and popular discontent in Nigeria. Princeton, NJ: Princeton University Press.

Sung, H. E. 2003. 'Fairer sex or fairer system-gender and corruption revisited', Social Forces 82, 2: $705^{-2} 5$.

Swamy, A., Y. Lee, O. Azfar \& S. Knack. 2001. 'Gender and corruption', Journal of Development Economics 64, 1: 25-55.

Titeca, K. \& T. De Herdt 2010. 'Regulation, cross-border trade and practical norms in West Nile, north-western Uganda', Africa 8o, 4: 573-94.

Vijayalakshmi, V. 2008. 'Rent-seeking and gender in local governance', Journal of Development Studies 44, 9: 1262-88.

World Bank. 2001. Engendering Development through Gender Equality in Rights, Resources, and Voice. Oxford University Press.

\section{Interviews}

Chef de poste, Customs, Keur Ayib, Kaolack Region, 18.3.2008.

Dembe, driver, Nioro, Kaolack Region, 29.2.2008.

Horse-cart driver, Kaolack Region, 4.3.2008.

Indicateur, Kaolack city, 23.3.2008.

Officer, Customs field office, Kaolack Region, 18.3.2008.

Omar, Ministry of Customs, Dakar, 10.4.2008. 